NBER WORKING PAPER SERIES

TOWARDS A THEORY OF CURRENT ACCOUNTS

Jaume Ventura

Working Paper 9163

http://www.nber.org/papers/w9163

NATIONAL BUREAU OF ECONOMIC RESEARCH

1050 Massachusetts Avenue

Cambridge, MA 02138

September 2002

This paper was prepared for a conference in honor of Max Corden, which took place at The Nitze School of Advanced International Studies in Washington, D.C. on April 2002. I am grateful to Pol Antrás for superb research assistance. The ideas presented here are the outcome of an ongoing research program that Aart Kraay and I have been developing in the last few years. The views expressed herein are those of the authors and not necessarily those of the National Bureau of Economic Research.

(C) 2002 by Jaume Ventura. All rights reserved. Short sections of text, not to exceed two paragraphs, may be quoted without explicit permission provided that full credit, including $(C$ notice, is given to the source. 
Towards a Theory of Current Accounts

Jaume Ventura

NBER Working Paper No. 9163

September 2002

JEL No. F21, F32

\begin{abstract}
$\underline{\text { ABSTRACT }}$
The current accounts data of industrial countries exhibits some strong patterns that are inconsistent with the intertemporal approach to the current account. This is the basic model that international economists have been using for more than two decades to think about current account issues. This paper shows that it is possible to go a long way towards reconciling the theory and the data by introducing two additional features to the basic model: investment risk and adjustment costs to investment. Moreover, these extensions generate new and unexpected theoretical predictions that receive substantial support in the data. The overall message is therefore positive: with a couple of reasonable modifications, the intertemporal approach to the current account provides a fairly good description of the industrial country data.

\author{
Jaume Ventura \\ Department of Economics \\ MIT \\ 50 Memorial Drive \\ Cambridge, MA 02139 \\ and NBER \\ jaume@mit.edu
}


There is substantial variation in current accounts both between and within countries. Figure 1 illustrates this point using a sample of 21 industrial countries covering the period 1966-1997. On average these countries ran a current account deficit of roughly 1 percent with a standard deviation of 3.1 percent. Going across the $\mathrm{X}$-axis, we find significant differences between countries in the long run or average current account, ranging from an average deficit of almost 5 percent in New Zealand to an average surplus close to 3 percent in the Netherlands. Going across the Y-axis, we also find that the differences within countries in the short run or year-to-year current account are considerable too. For instance, while Finland's average current account deficit is only 1.5 percent, over the sample period the current account has registered both a surplus of 5.6 percent in 1997 and a deficit of 7.6 percent in 1975. There is nothing remarkable about the Finnish experience. Year-to-year variation in current accounts has been even larger in other countries. ${ }^{1}$

What explains these differences in current accounts between and within countries? What is so different about New Zealand and the Netherlands that can explain their disparate current account experiences? What happened in 1975 and 1997 that justifies the dramatic difference in the Finnish current account? It is tempting to say that each country and year is a particular case, and that one needs to know the details to understand what is going on in the data. This must be true per force at some level. Any sound explanation of why New Zealand and the Netherlands have had such different experiences should be based on a detailed comparison of the institutions and histories of both countries. Similarly, any satisfactory account of why Finland's current account was so negative in 1975 and so positive in 1997 must be based on a thorough analysis of the economic events that took place around these dates.

Despite this, I believe it is important not to lose perspective and search for broad patterns and explanations that are common to all countries and dates. These patterns and explanations are the subject of this paper. A first premise therefore is

\footnotetext{
${ }^{1}$ The appendix provides a brief description of the data used in this paper.
} 
that the economic forces that drive the current account in New Zealand also operate in the Netherlands and in Finland, both in 1975 and 1997. A second premise is that these economic forces leave some traces in the data that can be identified with careful statistical analysis. In a nutshell, my goal here is not to explain the specific location of any two points in Figure 1, but instead to provide a coherent account of why the overall picture looks the way it does.

A few caveats are in order. The presentation is non-technical and it reflects my own views rather than those of the profession at large. I provide references throughout to papers that contain the formal models on which the discussion is based, including some written by researchers that do not agree with my views on the subject. There are also two self-imposed restrictions on the scope of the paper. The first one is that the story starts in the early 1980s when optimizing models took over the field of international macroeconomics. I have no doubt however that some (or perhaps all) of the basic ideas predate the use of formal models. The second restriction is that I focus on the current accounts of industrial countries. This is just to give the theory the best possible chance to succeed as the industrial country data is less affected by the debt crisis of the 1980s. Unfortunately, the theory reviewed here is not well equipped yet to provide a full account of this important episode.

\section{Basic Theory}

The aim of this section is to present the basic model that many economists have in their minds when they think about international capital flows. ${ }^{2}$ Underlying the model, there is the view that international financial markets allow industrial countries to borrow and lend from each other with only small or negligible transaction costs. This frictionless view of international borrowing and lending has strong empirical

\footnotetext{
${ }^{2}$ See Obstfeld and Rogoff [1995] and Razin [1995] for formal or mathematical presentations of this model.
} 
implications that can and have been confronted with the data. The first step is to derive them.

The theory starts by recognizing that saving rates differ across countries for a variety of reasons. Some of these differences in saving are only temporary. Countries are subject to transitory shocks to their income such as changes in the terms of trade, fluctuations in production, policy reforms, natural disasters and many others. It is usually assumed that individuals dislike fluctuations in consumption and use assets to buffer or smooth the consumption effects of transitory income shocks. This means raising saving during good times and lowering saving during bad times. To the extent that countries do not go through good and bad times all together, transitory income shocks provide a first source of cross-country differences in saving. But even if transitory income shocks are highly correlated across countries, they might still generate cross-country differences in saving if countries have different preferences for consumption smoothing. ${ }^{3}$

There are other cross-country differences in saving that are more permanent. Countries differ in their tax and social security laws, property rights and their enforcement and many other institutions. These factors affect the way individuals trade off present and future income. In other words, these factors determine the effective rate of time preference or discount rate of countries. Since "patient" countries save more than "impatient" ones, variation in the factors that determine the rates of time preference of countries constitute a second source of cross-country differences in saving.

The empirical evidence largely confirms the notion that there is substantial variation in saving rates across countries. This is shown in Figure 2. The average saving rate in the sample is about 22 percent and the standard deviation is 4.8 percent. The differences in long run or average saving rates between countries are

\footnotetext{
${ }^{3}$ For evidence on consumption-smoothing, see Deaton [1991] who reviews the evidence and concludes that "consumption is less volatile than income, it fluctuates less about its trend, the amplitude of its business cycle variation is less, and the variance of its growth rate is less than the variance of the growth rate of income" p.133-34.
} 
substantial, ranging from a low of about 17 percent in the United Kingdom to a high of about 33 percent in Japan. The latter is an outlier and most countries have an average saving rate somewhere between 18 and 25 percent. The differences in short run or year-to-year saving rates are even larger. In most countries the lowest saving rate is below 14 percent while the largest exceeds 26 percent. As mentioned, the theory interprets this variation in saving rates as the result of both consumptionsmoothing behavior and cross-country variation in the rate of time preference. ${ }^{4}$

The next step for the theory is to ask what do countries do with their saving. For the time being, I shall abstract from foreign investment and simply assume that countries have two investment opportunities: domestic capital and foreign loans. ${ }^{5}$ The wealth of the country $(\mathrm{W})$ is therefore equal to the domestic capital stock $(\mathrm{K})$ plus the foreign loans owned by the country $(F)$. That is, $W=K+F$. I shall refer to $F$ also as the net foreign asset position of the country. Creditor countries lend and have capital stocks that are smaller than their wealth, $\mathrm{W}>\mathrm{K}$ and $\mathrm{F}>0$; while debtor countries borrow and hold capital stocks in excess of their wealth, $\mathrm{W}<\mathrm{K}$ and $\mathrm{F}<0$. Net saving is equal to $\mathrm{S}=\Delta \mathrm{W}$. Net investment is equal to $\mathrm{I}=\Delta \mathrm{K}$ and the current account is $\mathrm{CA}=\Delta \mathrm{F}$. Any theory of the later must make assumptions on how countries choose their portfolios, i.e. how countries distribute their wealth between domestic capital and foreign loans.

Now a crucial assumption on how countries choose their portfolios is introduced. In particular, I shall adopt the view that countries adhere to this simple portfolio rule: "invest your wealth in domestic capital until its marginal product equals the world interest rate". This rule amounts to maximize the return to investment. Under fairly well known conditions, this rule is the optimal investment strategy of individual investors. As is customary in modern macroeconomics, the behavior of the country is the result of aggregating the behavior of these individual investors. Naturally, the private and social marginal product of capital might differ. In this case, the assumption that individual investors maximize the return to their investments does

\footnotetext{
${ }^{4}$ See Loayza, Schmidt-Hebbel and Servén [2000] for an analysis of the sources of cross-country variation in saving rates.

${ }^{5}$ Most international trade in assets consists of loans anyway. See Kraay, Loayza, Servén and Ventura [2000] for the evidence.
} 
not imply that the country as a whole maximizes the return to its investment. Although this distinction is important for policy and welfare analysis, it does not play any role in what follows.

The implications of adopting this portfolio rule for a small country are shown in Figure 3. Let $L$ be the labor force of the country, and let $A$ be a measure of the country's productivity. This measure reflects the quality of the country's technology and human capital. The MPK(K/L,A) schedule shows how the marginal product of capital varies as the capital stock increases. ${ }^{6}$ For a given labor force and productivity, increases in the capital stock reduce its marginal product as a result of the law of diminishing returns. Since the country is small, the world interest rate $(R)$ is unaffected by country variables. The domestic capital stock is determined by equating the marginal product of capital to the world interest rate, i.e. $M P K(K / L, A)=R$. Holding constant the interest rate, the capital-labor ratio is higher in those countries or years in which productivity is higher. This can be seen by comparing the equilibrium capital stock that corresponds to the schedule with high productivity $\left(A_{H}\right)$ with the one that corresponds to the schedule with low productivity $\left(A_{L}\right)$, i.e. $K_{H}>K_{L}$.

What is remarkable about the theory behind Figure 3 is that the wealth of the country plays no role in determining its capital-labor ratio. Holding constant productivity, the richer is the country the larger is its net foreign asset position but not its capital stock. The only channel through which changes in wealth can affect the capital stock of a country is the world interest rate. The assumption of frictionless international borrowing and lending means that the equilibrium interest rate is determined by the condition that the world demand for loans equals the world supply of loans or, alternatively, that the world demand for capital equals world wealth or the world supply of capital. Increases in wealth in a small country have only negligible effects on world wealth and the interest rate and, as a result, they also have negligible effects on the country's capital stock.

\footnotetext{
${ }^{6}$ If there are constant returns to scale, the MPK schedule depends only on the capital labor ratio and not on capital and labor separately. I implicitly assume this in the text.
} 
With this theory of country portfolios at hand, it is immediate to derive a theory of investment. Assume changes in the world supply and demand for capital are roughly equivalent and the interest rate is stable. Then, investment should be higher than average in those countries and years in which the growth rates of population and productivity are higher than average. Since the growth rates of these variables vary across countries for both permanent and temporary reasons, they constitute a source of variation in investment rates both between and within countries. Movements in the interest rate lead to synchronized movements in investment. If world saving is low and world average growth in population and productivity is high, the interest rate increases and this lowers investment in all countries. Naturally, the opposite applies in those years in which world saving is high and world average growth in population and productivity is low. Therefore, variation in the world interest rate can explain variation in investment rates within countries but not between countries.

Figure 4 shows that there is also substantial cross-country variation in investment rates. The average investment rate in the sample is about 23 percent and the standard deviation is 4.7 percent. The differences in long run or average investment rates between countries range from a low of 18 percent in the United Kingdom to a high of 32 percent in Japan. The short run or year-to-year variation in investment rates within countries is also substantial. In most countries the lowest investment rate is below 18 percent while the largest exceeds 28 percent. $A$ comparison of Figures 2 and 4 reveals that variation in investment rates both between and within countries is of roughly the same order of magnitude as the corresponding variation in saving rates. Despite this, the theory suggests that the factors that determine the variation in both variables are not the same. While the variation in saving rates is interpreted as the result of consumption smoothing and different rates of time preference, the variation in investment rates is interpreted as the result of different growth rates of population and productivity, as well as changes in world saving.

It is now straightforward to derive the implications of the theory for the current account. Remember that the current account is just the difference between saving 
and investment or, alternatively, the change in net foreign assets. The key feature of the theory is that investment should not be affected by saving (or the change in wealth). The latter only affects the current account (or the change in net foreign assets). To see this, assume that saving is unusually large in a given country and year. Perhaps this particular country is "patient" or perhaps in this particular year the country received a windfall and it wants to smooth its effects on consumption. This increase in wealth should have no effect on the capital stock, as Figure 3 shows. Since the increase in saving has no effect on investment, it should therefore lead to a one-to-one increase in the current account, i.e. $C A=\Delta F=\Delta W=S$. This is a strong prediction of the theory that can be confronted with the data. We turn to this task next.

\section{The Feldstein-Horioka Finding}

One approach to testing this prediction of the theory is to pool all country and year observations and run the following regression:

$$
\mathrm{CA}_{\mathrm{ct}}=\alpha+\beta \cdot \mathrm{S}_{\mathrm{ct}}+\mathrm{u}_{\mathrm{ct}}
$$

where the subscripts $c$ and $t$ denote country $c$ and year $t$, and $u_{c t}$ is a disturbance or error term. The estimate of $\beta$ obtained through this procedure should be interpreted as follows: "Assume that in country $c$ and year t saving is one percent higher than the sample average, then we should expect that in that same country and year the current account is $\beta$ times higher than the sample average." Finding an estimate of $\beta$ close to one would be encouraging for the theory, since the latter predicts that changes in saving should lead to one-to-one changes in the current account.

The top panel of Figure 5 and the first column of Table 1 show the result of estimating regression (1) using our sample of 21 industrial countries covering the period 1966-1997. The estimate of $\beta$ is 0.214 and, from a statistical standpoint, this estimate is significantly smaller than one. In other words, in our sample of industrial 
countries changes in saving are associated with changes in the current account that are only about one fifth of what the theory predicts. This result is important, but no longer surprising. In fact, this result is nothing but the famous finding of Feldstein and Horioka [1980] that saving and investment tend to move together. Another way to interpret the estimate of $\beta$ is that in countries and years in which saving is one percent higher than average, investment tends to be about four fifths of a percent higher than average. $^{7}$

This conclusion stands whether we compare the behavior of saving and the current account between or within countries. The middle panel of Figure 5 and the second column of Table 1 show the result of estimating regression (1) using long run or average values for the current account and saving. Once again, we find that if the long-run saving rate of a country is one percent higher than average, its long-run current account is expected to be 0.221 percent higher than average. Therefore, saving and investment are positively correlated between countries. The bottom panel of Figure 5 and the third column of Table 1 show the result estimating regression (1) using a fixed-effects regression. ${ }^{8}$ Once again, we find that if in a given year saving is one percent higher than the country's long-run average, in this year the current account is expected to be 0.203 percent higher than the country's long-run average. Therefore, saving and investment are also positively correlated within countries. Interestingly, we find that regardless of whether we estimate regression (1) using the between or within country variation, a one percent increase in saving is associated with an increase in the current account of only one fifth of a percent.

Is this evidence very damaging for the theory? Not necessarily. The theory emphasizes the role of consumption smoothing and differences in the rates of time preference as a source of cross-country variation in saving. It is a priori unlikely that these factors have a large effect on investment. But many international economists have correctly argued that there are other determinants of saving that might also

\footnotetext{
${ }^{7}$ See Tesar [1991] for a survey of the literature that followed the Feldstein-Horioka finding.

${ }^{8}$ This is equivalent to subtracting country means to the data before estimating regression (1). By taking out country means, the fixed-effects regression only uses time-series or within country variation to determine the coefficient $\beta$.
} 
influence investment. For instance, Franco Modigliani's life-cycle theory of saving predicts that countries with high rates of population and productivity growth should have high saving rates, as in these countries the saving of younger generations is large relative to the dissaving of the older ones. These are exactly the variables that the theory points out as the main sources of cross-country variation in investment. To the extent that life-cycle motives are important determinants of saving, we should expect saving and investment to be positively correlated both between and within countries.

The theory also emphasizes the role of idiosyncratic or country-specific shocks as a source of cross-country differences in saving. But consider the possibility that countries receive common or global shocks that affect their saving. Since the world is a closed economy, in those years when saving is high worldwide the world interest rate is low and investment is high in all countries. The opposite occurs when world saving is low. Therefore, common or global shocks generate synchronized movements in saving and investment. To the extent that these shocks are important, we should expect saving and investment to be positively correlated within countries.

If we extend the theory to allow for the presence of these common sources of variation in saving and investment, its main prediction becomes conditional: changes in saving due to consumption smoothing and/or changes in the rate of time preference should lead to a one-to-one changes in the current account. If we do not control for these common sources of variation in saving and investment, the estimate of $\beta$ obtained from regression (1) is biased toward zero. This is why many international economists have not interpreted the low estimate of $\beta$ as a rejection of the basic theory. Instead, they have interpreted the low estimate of $\beta$ as evidence of the importance of common sources of variation in saving and investment. This interpretation has been very popular because it is quite plausible a priori and, in addition, it generates a strong testable prediction: if we control for common sources of 
variation in saving and investment when we estimate equation (1), we should retrieve an estimate of $\beta$ close to one. ${ }^{9}$

To test this prediction of the extended theory, I re-estimate regression (1) using time dummies and measures of productivity and population growth as control variables. The time dummies should capture global or common shocks. The results are presented in the last three columns of Table 1. In some specifications these controls are statistically significant. But, as many others have found before, these controls have little or no effect on the estimate of $\beta$. Naturally, one could argue that these controls are not sufficient. Perhaps there are other common sources of variation in saving and investment that have not been found yet. And it might well be that when we find them, the theory proves to be correct. This is in fact the view or position that most international economists have adopted. There is nothing illogical about this view. But two decades and hundreds (thousands?) of regressions after Feldstein and Horioka [1980], I am quite skeptical that we will ever find these common sources of variation. ${ }^{10}$

There is another and perhaps more direct way to document the failure of the basic theory. It consists of directly examining the evidence on country portfolios. Remember that the theory predicts that differences in wealth should not lead to differences in capital stocks, since the latter are only determined by differences in productivity. Figure 6 plots the average capital-labor ratio, K/L, against average wealth per capita, W/L, for the 21 industrial countries in our sample. One does not need sophisticated econometric techniques to conclude that there is a strong relationship between these two variables. Basically all points are located near the $45^{\circ}$ line, indicating that the capital stock is roughly of the same magnitude of wealth in all countries and net foreign asset positions are very small. At first sight, this evidence

\footnotetext{
${ }^{9}$ Another way to proceed would be to find a source of variation in saving that we know as a matter of fact has no direct effects on investment. Using this variable as an instrument in regression (1), we would obtain an unbiased estimate of $\beta$. The problem, of course, is finding this variable.

${ }^{10}$ Even if we found them now, I would probably remain skeptical that this is not the result of a collective data mining effort. After so many regressions, what is the probability of finding a spurious control variable that has just the right correlations with saving and the current account to raise the estimate of $\beta$ up to one?
} 
seems to go against the view that the distribution of wealth has no effects on the distribution of capital stocks.

Naturally, one can argue again that we should simply extend the theory to recognize that there are common sources of variation in wealth and capital stocks. Now the argument runs as follows: The same sort of institutions that promote patience and therefore lead to high saving and wealth also promote productivity growth and therefore lead to high investment and capital stocks. Since there is plenty of evidence that rich countries also have better technologies and more human capital, this positive correlation could explain the evidence in Figure 6.

I find the premise behind this view plausible, but I do not think this argument can restore the credibility of the basic model. A first reason is that it might at best explain why there is a positive correlation between wealth and capital stocks. But what is truly surprising in Figure 6 is not that wealth and capital stocks exhibit a positive correlation, but instead how strong this correlation is. A second and more important reason is that the extended theory still predicts that wealth should not have any effect on the capital-labor ratio of the country if we control for the country's level of productivity. However Kraay, Loayza, Servén and I [2000] showed that even after controlling for differences in human capital, technology and institutions, wealth remains the variable that better explains the cross-country distribution of capital stocks. Naturally, this is also subject to the caveat that we might not be choosing the right controls for productivity. But we used the main variables that the growth literature has used to control for productivity and we still failed to eliminate the large influence of wealth on capital stocks. After having looked at Figure 6 one should not be surprised by this failure. And this is actually the point I wanted to make here. 


\section{Investment and the Current Account}

There is another interesting empirical regularity that concerns the relationship between investment and the current account. To derive it, consider the following regression: ${ }^{11}$

$$
\mathrm{CA}_{\mathrm{ct}}=\alpha+\beta \cdot \mathrm{I}_{\mathrm{ct}}+\mathrm{u}_{\mathrm{ct}}
$$

The basic theory would predict that the estimate of $\beta$ is close to minus one, since changes in investment should not affect saving. Naturally, we no longer expect this result to hold given the results of estimating regression (1). The top panel of Figure 7 and the first column of Table 2 show the pooled version of regression (2) and confirm this. The estimate of $\beta$ is -0.188 indicating a weak negative relationship between investment and the current account.

What is interesting about regression (2) is how different the between and within results are. The middle and bottom panels of Figure 7 and the second and third columns of Table 2 show that the pooled results "average" very different patterns of behavior in the long and short run. In the between regression, the estimate of $\beta$ is close to zero. Countries that invest more on average do not run larger current account deficits on average. Penati and Dooley [1991] were the first to document this empirical regularity. ${ }^{12}$ In the within regression however, the estimated $\beta$ is -0.327 . In those years when a country invests more than average, the country also tends to run larger current account deficits than average. Glick and Rogoff [1995] were the first to document this result. The last three columns of Table 2 show that this difference between the long and short run relationship between investment and the current account is not affected when we use control variables.

\footnotetext{
${ }_{11}^{11}$ Sachs [1981] was the first one to run this regression.

12 Sachs [1981] argued that the between regression yields a negative coefficient. Penati and Dooley [1991] showed that Sachs' result depended crucially on a few outliers.
} 
The data therefore show quite clearly that investment and the current account are uncorrelated between countries, but negatively correlated within countries. These facts are difficult to interpret from the vantage point of the basic theory. The later would predict that changes in investment lower the current account one-to-one. This is true both in the long and short run. The argument that there are global shocks to saving could explain that within countries investment and the current account deficit move less than one-to-one. But why is it that in the long run countries that invest more do not have larger current account deficits? It seems unlikely that the basic theory will be able to answer this question.

To sum up, any successful theory of the current account should be able to answer these two questions:

1) Why are saving and investment so highly correlated both in the long and the short run?

2) Why are investment and the current account negatively correlated in the short run and not correlated at all in the long run?

The basic theory of section 1 fails to provide a satisfactory account of these empirical regularities. But this does not mean that the theory is mortally wounded. In the last few years, Aart Kraay and I [2000, 2002] have devoted a substantial amount of time to the task of showing why and how the theory can be fixed. In the next two sections, I shall draw on our joint work and argue that a couple of reasonable modifications of the basic theory can lead us a long way towards reconciling the theory and the evidence. Moreover, these modifications will in turn generate new and unexpected empirical implications that are largely supported by the data. After a bit of surgery, the theory seems to be alive and kicking. 


\section{Revisiting the Basic Model (I): Investment Risk}

Implicit in the investment rule of the basic theory is the view that individual investors either do not face investment risk or, if they do, they do not care about it. This is why their only objective when choosing a portfolio is to maximize its return. But this is clearly a simplification. In the real world, investors face a trade-off between maximizing the return to their portfolio and minimizing its risk. They are in general willing to buy assets that offer a low return if these assets allow them to hedge part of the risk in their portfolios. To make this observation operative, I shall modify the assumption on how countries choose their portfolios as follows: "invest your wealth in domestic capital until its marginal product equals the world interest rate plus the appropriate risk premium". Investors require the latter as a compensation for the risk associated with real investments. ${ }^{13}$

Figure 8 shows the implications of this modified portfolio rule for a small country. The novelty with respect to Figure 3 is the presence of a risk premium or $\mathrm{RP}(\mathrm{K} / \mathrm{W})$ schedule. ${ }^{14}$ For a given level of wealth, an increase in the capital stock raises the correlation between the return to capital and the return to the country portfolio since the latter now contains more capital. This in turn increases the risk premium that investors require to hold additional units of capital. The capital stock is now determined by equating the marginal product of capital to the world interest rate plus the risk premium, i.e. $M P K(K / L, A)=R+R P(K / W)$. Holding constant population and wealth, the capital stock is higher in countries or years in which productivity is higher. To see this, just compare points $A$ and $B$ (or points $C$ and $D$ ). This was also the case in the basic theory of section 1 . The key difference now is that wealth also affects the capital stock. Holding constant population and productivity, the higher the wealth of the country the higher is its capital stock. To see this, compare points $A$ and $C$ (or points $B$ and $D$ ). Now a high productivity country that is poor (point $B$ ) might have the

\footnotetext{
${ }^{13}$ See Kraay and Ventura [2000] for a formal or mathematical presentation of this model. Ventura [2001] uses this model to analyze the U.S. current account deficit.

${ }^{14}$ If preferences are homothetic and returns lognormal, the RP schedule depends only on the share of capital in wealth and not on capital and wealth separately. These assumptions underlie the meanvariance theory of Harry Markowitz and James Tobin and I implicitly adopt them in the text.
} 
same capital stock as a low productivity country that is rich (point C). Once we generalize the basic theory to allow for the presence of investment risk, both productivity and wealth have direct effects on the capital stock.

The basic theory of section 1 can now be reinterpreted as the special case of the general theory of this section in which diminishing returns are strong and investment risk is weak. Under these conditions, the MPK schedule is steep and the RP schedule is flat. Another way to say this is that the marginal product of capital is very sensitive to the changes in $\mathrm{K} / \mathrm{L}$ but the risk premium is not very sensitive to changes in K/W. As already discussed, this special case has dominated academic research in the field of international macroeconomics for two decades. Part of the success of this special case must be attributed to the fact that it generates such a simple and straightforward rule: "Changes in saving lead to one-to-one changes in the current account". Kraay and I [2000] have labeled this the traditional rule. As shown already, the traditional rule provides a poor description of the data. This is discouraging because the general model of Figure 8 seems quite difficult to work with, and it is unlikely to yield such a simple rule governing the relationship between saving and the current account.

Fortunately, there is another special case of the general model that generates an equally simple and straightforward empirical implication. Assume, contrary to the traditional rule, that diminishing returns are weak and investment risk is strong. That is, assume that the RP schedule is steep and the MPK schedule is flat. This is the case depicted in Figure 9. This special case has the property that changes in wealth lead to changes in the capital stock that keep the share of domestic capital in the country portfolio constant. That is, a change in $\mathrm{W}$ leads to a change in $\mathrm{K}$ that keeps $\mathrm{K} / \mathrm{W}$ constant. To see this, note that $\mathrm{K} / \mathrm{W}$ is the same in points $\mathrm{A}$ and $\mathrm{C}$ (and also in points $B$ and $D$ ). In other words, the country invests the marginal unit of wealth as the average one $\Delta \mathrm{K} / \Delta \mathrm{W}=\mathrm{K} / \mathrm{W}$. Define $\mathrm{X}$ as the share of foreign loans in the country portfolio, i.e. $X=F / W=1-K / W$. Then, this special case generates the new rule that "Changes in saving lead to changes in the current account that are proportional to X". 
The new rule is an unexpected result of the theory. ${ }^{15}$ Moreover, the new rule is as simple as the traditional rule and can be tested using the same procedures.

The economic intuition behind the new rule is easy to understand. If investment risk is important investors have a strong desire for diversification that makes them reluctant to rebalance their portfolios toward any given asset. This is just the old cliché that "one should not put all the eggs in the same basket". If diminishing returns are weak increases in the capital stock have little effect on its marginal product and provide small incentive for investors to rebalance their portfolios. In the limiting case of the new rule, countries invest their marginal unit of saving just as the average one and the country portfolio remains stable. Therefore, we can interpret the new rule as the prediction that changes in saving lead to portfolio growth, i.e. changes in the size of the country portfolio without affecting its composition.

Although the ingredients behind the new rule are quite standard, some of its implications are counterintuitive for those that have been schooled within the basic theory of section 1. To see this, consider the effects of an increase in saving due to, say, a production boom, diminished expectations about the future, a reduction in taxes or an increase in population growth. The traditional rule would say that most or all of this saving should be invested abroad, leading to an increase in the current account surplus. Instead, the new rule says that this saving should be invested in the same proportions as in the existing portfolio, leading to an increase in the current account surplus in creditor countries, i.e. $X>0$, and a decrease in debtor countries, i.e. $X<0$. Therefore, the current account effects of transitory income shocks are quite different in creditor and debtor countries.

What determines the composition of the country portfolio in the "new rule" model? Cross country variation in productivity. Countries with high productivity will tend to have a higher capital stock and a lower net foreign asset position, i.e. X. To see this, go back to Figure 9 and note that $\mathrm{K} / \mathrm{W}$ is higher in the high productivity

\footnotetext{
${ }^{15}$ At least, it was unexpected to Kraay and me when we first thought about it.
} 
country, i.e. points $B$ and $D$, than in the low productivity country, i.e. points $A$ and $C$. Since net foreign asset positions are small (remember Figure 6), one might infer from this that cross-country differences in productivity among industrial countries are not that large. Whether these net foreign asset positions are stable over time depends upon the extent to which productivity growth varies across countries. The larger is the cross-country variation in productivity growth, the larger are the changes in the composition of country portfolios, i.e. changes in X. I refer to these changes as portfolio rebalancing.

To test the new rule, I pool again all country and year observations and run the following regression:

$$
\mathrm{CA}_{\mathrm{ct}}=\alpha+\beta \cdot \mathrm{X}_{\mathrm{ct}} \cdot \mathrm{S}_{\mathrm{ct}}+\mathrm{u}_{\mathrm{ct}}
$$

If the new rule provides a good description of the data we should find an estimate of $\beta$ close to one. The results are presented in the top panel of Figure 10 and the first column of Table 3. The estimate of $\beta$ is very close to one and the simple interaction of saving and the share of foreign assets explains about 30 percent of the observed variation in current accounts. These results are surprisingly good for the theory and seem to suggest that the new rule has substantial predictive power.

The top panel of Figure 10 hides however a large discrepancy in the success of the new rule to describe the long and the short run data. The middle and bottom panels of Figure 10 and the second and third columns of Table 3 show this. The new rule explains the bulk of the variation in current accounts between countries. The between regression delivers and estimate of $\beta$ which is practically equal to one and the interaction variable explains more than 80 percent of the variation in the data. But the new rule explains basically none of the variation in current accounts within countries. The within regression delivers and estimate of $\beta$ which is well below one and the interaction variable explains none of the variation in the data. These results clearly indicate that there is a discrepancy between the short and long run behavior of 
the current account. The last three columns of Table 3 show that this discrepancy remains even if we control for common sources of variation in saving and investment.

So what should we conclude from this evidence? The new rule works very well in explaining the long run data. The middle panel of Figure 10 shows that, in the long run, the current account is basically portfolio growth. Since net foreign asset positions are small, $X \approx 0$, portfolio growth implies that increases in saving generates increases in investment of roughly the same magnitude, i.e. $\Delta \mathrm{K}=(1-\mathrm{X}) \cdot \Delta \mathrm{W}$. This is how the new rule explains the strong correlation between saving and investment in the long run. The new rule also provides a very simple explanation of why there is a near zero correlation between investment and the current account in the long run. In creditor countries, increases in saving raise investment less than one-to-one and generate current account surpluses. In debtor countries, increases in saving raise investment more than one-to-one and generate current account deficits. Therefore, investment and the current account should be positively correlated in creditor countries, but negatively correlated in debtor ones. Our sample contains both types of countries and the near zero correlation between investment and the current account in the long run is just an artifact of forcing a single relationship for all of them. Figure 11 separates countries into creditors and debtors and shows that investment and the current account are positively correlated among the former but negatively correlated among the later.

The new rule does not work nearly as well in explaining the short run data. The bottom panel of Figure 10 clearly shows this. But the theory, with its focus on the behavior of the country portfolio, helps us frame the issues. If we want to understand why the new rule performs so poorly in the bottom panel of Figure 10, we must explain how and why in the short run increases in saving lead mostly to portfolio rebalancing. But the middle panel of Figure 10 shows that in the long run increases in saving lead mostly to portfolio growth. If we want to reconcile the middle and bottom panels of Figure 10, we must go further and also explain how and why this short-run portfolio rebalancing is undone in the long run. To do all of this, we just need to introduce one additional element into the theory. 


\section{Revisiting the Basic Model (II): Adjustment Costs}

Implicit in the general model of Figure 8 (and therefore also in the traditional and new rule special cases in Figures 3 and 9) is the view that countries can change their capital stock with small or negligible costs of adjustment. This is why fluctuations in investment have no effect on the marginal product of capital. Naturally, this is just another simplification of the theory. In periods of high investment, resources are diverted from production activities to investment activities. Moreover, new units of capital are different than old ones and workers need to learn how to use them. For these and many other reasons it is likely that the marginal product of capital declines with the investment rate. If this is the case, we must modify the MPK schedule to recognize this, i.e. $M P K(K / L, A, \Delta K)$. I shall show in this section that, with this second and also reasonable modification, the theory can explain not only the long run patterns in the data, but also the short run ones. Once again, this modification will lead us to an unexpected and new empirical implication that receives substantial support in the data. ${ }^{16}$

Figure 12 shows the effect of introducing adjustment costs to the "new rule" model. Consider an increase in saving that raises wealth from $W_{L}$ to $W_{H}$. Without adjustment costs, the country would move from A to $C$ directly. In this case the country portfolio would not change, i.e. $\mathrm{K} / \mathrm{W}$ is constant. That is, the new rule applies and the current account equals portfolio growth. Assume instead the more realistic case in which adjustment costs to investment are important. The increase in saving raises investment from its normal level, i.e. $\Delta \mathrm{K}_{\mathrm{N}}$, to a higher level, i.e. $\Delta \mathrm{K}_{\mathrm{H}}$, and the MPK schedule shifts downward. This induces investors to rebalance their portfolio towards foreign assets, i.e. K/W declines, and the capital stock grows less that what would be predicted by the new rule. The short run equilibrium is in point $B$. As investment returns to normal, the MPK schedule shifts back to its original position and the country rebalances its portfolio back towards its initial composition. The long run equilibrium is in point $\mathrm{C}$. The presence of adjustment costs to investment can

\footnotetext{
${ }^{16}$ See Kraay and Ventura [2002] for a formal or mathematical presentation of this model.
} 
therefore explain why an increase in saving generates portfolio rebalancing in the short run and how this rebalancing is undone in the long run.

This theoretical picture has strong empirical implications for the dynamic response of the current account to an increase in saving. Assume that a country enjoys a windfall and decides to save it so as to smooth its consumption over time. In the short run, the country would convert a large portion of this saving into foreign assets and the new rule would under-predict the current account, i.e. X.S $<\mathrm{CA}$. This short-run or impact effect reflects the movement from A to B in Figure 12. Over time, the country would convert these foreign assets into domestic capital and the new rule would over-predict the current account, i.e. X.S>CA. This adjustment process reflects the movement from $B$ to $C$ in Figure 12, when saving has returned to average and yet the current account is more negative or less positive than average. In the long run, the increase in saving ends up being invested in the same proportions as the initial portfolio and the current is equal to new rule, $C A=X \cdot S$.

To test this prediction, Kraay and I [2002] constructed the portfolio rebalancing component of the current account, i.e. PR=CA-X.S, and estimated a series of dynamic linear regressions of the form:

$$
\mathrm{PR}_{\mathrm{ct}}=\alpha_{\mathrm{c}}+\sum_{\mathrm{v}=1}^{\mathrm{p}} \phi_{\mathrm{v}} \cdot \mathrm{PR}_{\mathrm{c}, \mathrm{t}-\mathrm{v}}+\sum_{\mathrm{v}=0}^{\mathrm{q}} \gamma_{\mathrm{v}} \cdot \mathrm{S}_{\mathrm{c}, \mathrm{t}-\mathrm{v}}+\beta^{\prime} \mathrm{Z}_{\mathrm{ct}}+\mathrm{u}_{\mathrm{ct}}
$$

where $Z_{c t}$ is a vector of control variables, and $u_{c t}$ is a well-behaved error term. The vector of control variables contained year dummies and the now familiar measures of population and productivity growth. We then used the point estimates of the coefficients to retrieve the implied impulse response function of portfolio rebalancing in period $t+k$ to an increase in saving in period t, i.e. $\frac{\partial P R_{c, t+k}}{\partial S_{c t}}$. These impulse responses provide us with a picture of how countries change the composition of their portfolios following an increase in saving. 
Figure 13 shows a typical impulse-response function constructed in this way. On impact, countries rebalance their portfolios towards foreign assets and the new rule systematically under-predicts the short-run effects of increases in saving on the current account. In particular, the current account surplus generated by a one percent increase in savings is about three fourths of a percent larger than what the new rule would predict. As a result, the net foreign asset position increases. In the years that follow, countries rebalance their portfolios back towards their original composition. During this period, the new rule systematically over-predicts the current account but by a declining amount. The net foreign asset position declines and slowly returns to its original level. This adjustment process lasts about four or five years. The picture that comes out from Figure 13 turns out to be quite robust to a number of specification and data checks. ${ }^{17}$ Overall, the evidence is consistent with the view that adjustment costs are important and, to avoid paying them, countries use foreign assets as a buffer stock to smooth fluctuations in investment.

The model with adjustment costs has the same predictions for the long run data than the simple new rule model. As a result this model can account for both the strong correlation between saving and investment in the long run and the near zero correlation between investment and the current account in the long run. Both facts are an implication of the finding that, in the long run, the new rule applies and the current account is simply portfolio growth. But unlike the simple new rule model, the new rule model with adjustment costs can also explain the main features of the short run data. We have already seen that its predictions about the short and long run behavior of portfolio rebalancing are supported by the data and it is straightforward to see that the model also implies a positive correlation between saving and investment in the short run. It is less straightforward but also true that the new rule model with adjustment costs is also consistent with the negative correlation of investment and the current account in the short run. The within-country correlation between

\footnotetext{
${ }^{17}$ See Kraay and Ventura [2002] for a robustness analysis. In particular, we show that the pattern described in Figure 13 is robust to (i) changes in the lag structure, (ii) permitting parameter heterogeneity, (iii) introducing controls for shocks to asset returns that are possibly correlated with saving, (iv) the use of higher frequency data.
} 
investment and the current account can be decomposed into two components. First, there is the positive correlation that arises from the movement from $A$ to $B$ in Figure 12. Second, there is the negative correlation that arises from the movement from $B$ to

C. If adjustment costs to investment are strong enough and the adjustment process is sufficiently protracted, this second component dominates and the overall correlation is negative. This is exactly what we find in Kraay and Ventura [2002].

\section{The Challenges Ahead}

The starting point of this paper was the observation that there are some patterns in the current accounts of industrial countries that are inconsistent with the basic theory that international economists have been using for more than two decades. I then showed that it is possible to go a long way towards reconciling the theory and the data by introducing two additional features to the basic model:

investment risk and adjustment costs. The key insights reported here are the new rule and its extension to the case of adjustment costs. The new rule says: "countries invest at the margin as they do on average". That is, country portfolios tend to be stable. The new rule with adjustment costs introduces the following caveat: "but this might take a little while". That is, there are predictable but transitory changes in the country portfolio following a shock. Taking as given the long-run country portfolio, the theory presented here provides a surprisingly accurate account of the joint behavior of savings, investment and the current account. The overall message is therefore positive: with a couple of reasonable modifications, the intertemporal approach to the current account provides a fairly good description of the industrial country data.

But why are country portfolios the way they are? The theory views the country portfolio as the optimal (at least from an individual standpoint) trade-off between the risk and return of holding domestic capital. Countries with better technologies and less aversion towards risk should be more willing to leverage themselves and hold smaller net foreign asset positions. Data on country portfolios show that net foreign 
asset positions are small and very persistent. ${ }^{18}$ To reconcile this observation with the theory, one must postulate that technologies and attitudes towards risk exhibit little variation in both the cross-sectional and time-series dimensions. This does not seem unreasonable as a description of industrial countries. It is tempting therefore to conclude that the next step to achieve a good understanding of country portfolios consists of performing more and better empirical work trying to relate the variation in these country characteristics with the variation in net foreign asset positions.

While this empirical work is badly needed, it will not be enough. Implicit in the models discussed in this paper there is the view that international borrowing and lending (i.e. trade across dates) is possible with very small or negligible transaction costs, but international risk sharing (i.e. trade across states of nature) is either quite costly or not possible at all. Remember we have assumed throughout that the only assets traded internationally are riskless loans. This assumption plays an important role in the general model of section 4 . To see this, assume instead that investors can buy and sell claims to the returns of domestic and foreign capital. They could then reduce their exposure to domestic investment risk without lowering their return by holding a well-diversified portfolio that includes claims to the return of domestic and foreign capital. Under these circumstances, the risk premium associated with domestic capital is not likely to be very sensitive to domestic investment. If the latter offers a high return, countries can always invest and then sell the risk associated with this investment. The implication is clear and unsettling: if countries are able to sell the risk associated with domestic investments we return to the special case of the basic theory of section $1 !^{19}$

Let me hasten to say that I have not gone around a circle just to leave the reader exactly where it all started. The assumption that countries are unable or unwilling to sell the risk associated with domestic investment provides an excellent description of reality. There are many papers that document this, starting with French

\footnotetext{
${ }^{18}$ See Kraay, Loayza, Servén and Ventura [2000] for a description of country portfolios.

${ }^{19}$ That is, if countries are able to sell their risk the RP schedule is likely to be flat and this converts the general model in Figure 8 into the special case in Figure 3.
} 
and Poterba [1991]. The question here is not "whether" but "why". The theory works well under the assumption that there is limited international risk sharing, and the data confirms that this is the case. But this still leaves open the question of why is it that industrial countries do not buy insurance or diversify their investment risk away. ${ }^{20}$ Answering this question is one of the major challenges we have ahead of us. The other, of course, is to figure out what is going on in emerging markets.

\section{Appendix: Data Description}

To construct the different tables and figures I have used data on current accounts, investment, saving, capital stocks and wealth. The share of net foreign assets in wealth is one minus the ratio of the capital stock to wealth. I obtained annual data on data on current accounts in current US dollars from the International Monetary Fund's International Financial Statistics. I obtained investment and GDP from the World Bank's World Development Indicators. I then measure gross national saving as the sum of the current account and gross domestic investment in current US dollars, and express both as a fraction of GDP in current US dollars. I obtain data on capital stocks and wealth from Kraay, Loayza, Servén and Ventura (2000). I restrict attention to the set of 21 industrial countries for which at least 20 annual observations on this variable are available over the period 1966-1997.

\section{References}

Deaton, Angus. Understanding Consumption. Oxford: Clarendon Press, 1992.

Feldstein, Martin, and Charles Horioka, "Domestic Saving and International Capital Flows," Economic Journal, XC (1980), 314-329.

\footnotetext{
${ }^{20}$ See Lewis [1999] for a survey of various attempts to answer this question.
} 
French, Kenneth and James Poterba, "Investor Diversification and International Equity markets," American Economic Review, LXXXI (1991), 222-226.

Glick, Reuven and Kenneth Rogoff, "Global versus Country-Specific Productivity Shocks and the Current Account," Journal of Monetary Economics,"35 (1995), 159-192.

Kraay, Aart, Norman Loayza, Luis Servén, and Jaume Ventura, "Country Portfolios," NBER Working Papers, No. 7795, July 2000.

Kraay, Aart, and Jaume Ventura, "Current Accounts in Debtor and Creditor Countries," Quarterly Journal of Economics, XCV (2000), 1137-1166.

Kraay, Aart, and Jaume Ventura, "Current Accounts in the Long and Short Run," 2002 NBER Macroeconomics Annual, forthcoming.

Lewis, Karen, "Trying to Explain Home Bias in Equities and Consumption," Journal of Economic Literature, XXXVII (1999), 571-608.

Loayza, Norman, Klaus Schmidt-Hebbel and Luis Servén, "What Drives Private Saving Around the World?" The Review of Economics and Statistics, LXXXII (2000), 165-181.

Obstfeld, Maurice, and Kenneth Rogoff, "The Intertemporal Approach to the Current Account," in Gene Grossman and Kenneth Rogoff, eds., Handbook of International Economics. Elsevier, 1995.

Penati, Alessandro and Michael Dooley, "Current account imbalances and capital formation in industrial countries, 1949-81," IMF Staff Papers 31 (1984), 1-24.

Razin, Assaf, "The Dynamic-Optimizing Approach to the Current Account: Theory and Evidence" in P.B. Kenen, ed. Understanding Interdependence: The Macroeconomics of the Open Economy. Princeton University Press, 1995.

Sachs, Jeffrey, "The Current Account and Macroeconomic Adjustment in the 1970s," Brookings Papers on Economic Activity, 1 (1981), 201-268.

Tesar, Linda, "Saving, Investment and International Capital Flows," Journal of International Economics, XXXI (1991), 55-78.

Ventura, Jaume, "A Portfolio View of the U.S. Current Account Deficits". Brookings Papers on Economic Activity. (2001), July. 
Table 1. Saving and the Current Account

\begin{tabular}{|c|c|c|c|c|c|c|}
\hline & $\begin{array}{c}\text { Pooled } \\
\text { Regression } \\
(1)\end{array}$ & $\begin{array}{c}\text { Between } \\
\text { Regression } \\
\text { (2) }\end{array}$ & $\begin{array}{c}\text { Within } \\
\text { Regression } \\
\text { (3) }\end{array}$ & $\begin{array}{c}\text { Pooled } \\
\text { Regression } \\
(4)\end{array}$ & $\begin{array}{c}\text { Between } \\
\text { Regression } \\
(5)\end{array}$ & $\begin{array}{c}\text { Within } \\
\text { Regression } \\
(6)\end{array}$ \\
\hline $\begin{array}{l}\text { Growth National } \\
\text { Saving/GDP }\end{array}$ & $\begin{array}{c}0.214 \\
(0.023)\end{array}$ & $\begin{array}{c}0.221 \\
(0.074)\end{array}$ & $\begin{array}{c}0.203 \\
(0.030)\end{array}$ & $\begin{array}{c}0.242 \\
(0.025)\end{array}$ & $\begin{array}{c}0.220 \\
(0.100)\end{array}$ & $\begin{array}{c}0.343 \\
(0.043)\end{array}$ \\
\hline Productivity Growth & & & & $\begin{array}{l}-0.048 \\
(0.053)\end{array}$ & $\begin{array}{l}-0.269 \\
(0.648)\end{array}$ & $\begin{array}{l}-0.044 \\
(0.042)\end{array}$ \\
\hline Population growth & & & & $\begin{array}{l}-0.789 \\
(0.182)\end{array}$ & $\begin{array}{l}-0.829 \\
(0.932)\end{array}$ & $\begin{array}{l}-0.631 \\
(0.246)\end{array}$ \\
\hline $\mathrm{R}^{2}$ & 0.116 & 0.194 & 0.070 & 0.280 & 0.240 & 0.317 \\
\hline Number of observations & 640 & 21 & 640 & 638 & 21 & 638 \\
\hline $\begin{array}{l}\text { P-value for null } \\
\text { hypothesis that } \\
\text { coefficient on } \\
\text { savings }=1 \\
\end{array}$ & 0.000 & 0.000 & 0.000 & 0.000 & 0.000 & 0.000 \\
\hline
\end{tabular}


Table 2. Investment and the Current Account

\begin{tabular}{|c|c|c|c|c|c|c|}
\hline & $\begin{array}{c}\text { Pooled } \\
\text { Regression } \\
(1)\end{array}$ & $\begin{array}{c}\text { Between } \\
\text { Regression } \\
\text { (2) }\end{array}$ & $\begin{array}{c}\text { Within } \\
\text { Regression } \\
\text { (3) }\end{array}$ & $\begin{array}{c}\text { Pooled } \\
\text { Regression } \\
(4)\end{array}$ & $\begin{array}{c}\text { Between } \\
\text { Regression } \\
\text { (5) }\end{array}$ & $\begin{array}{c}\text { Within } \\
\text { Regression } \\
(6)\end{array}$ \\
\hline $\begin{array}{l}\text { Growth Domestic } \\
\text { Investment/GDP }\end{array}$ & $\begin{array}{l}-0.188 \\
(0.030)\end{array}$ & $\begin{array}{l}-0.030 \\
(0.133)\end{array}$ & $\begin{array}{l}-0.327 \\
(0.033)\end{array}$ & $\begin{array}{l}-0.207 \\
(0.034)\end{array}$ & $\begin{array}{l}-0.097 \\
(0.168)\end{array}$ & $\begin{array}{l}-0.432 \\
(0.045)\end{array}$ \\
\hline Productivity Growth & & & & $\begin{array}{c}0.171 \\
(0.051)\end{array}$ & $\begin{array}{c}0.307 \\
(0.725)\end{array}$ & $\begin{array}{c}0.169 \\
(0.050)\end{array}$ \\
\hline Population growth & & & & $\begin{array}{l}-1.039 \\
(0.163)\end{array}$ & $\begin{array}{l}-1.164 \\
(0.619)\end{array}$ & $\begin{array}{l}-0.338 \\
(0.226)\end{array}$ \\
\hline$R^{2}$ & 0.086 & 0.003 & 0.215 & 0.247 & 0.124 & 0.411 \\
\hline Number of observations & 640 & 21 & 640 & 638 & 21 & 638 \\
\hline $\begin{array}{l}\text { P-value for null } \\
\text { hypothesis that } \\
\text { coefficient on } \\
\text { investment }=-1\end{array}$ & 0.000 & 0.000 & 0.000 & 0.000 & 0.000 & 0.000 \\
\hline
\end{tabular}


Table 3. Testing the New Rule

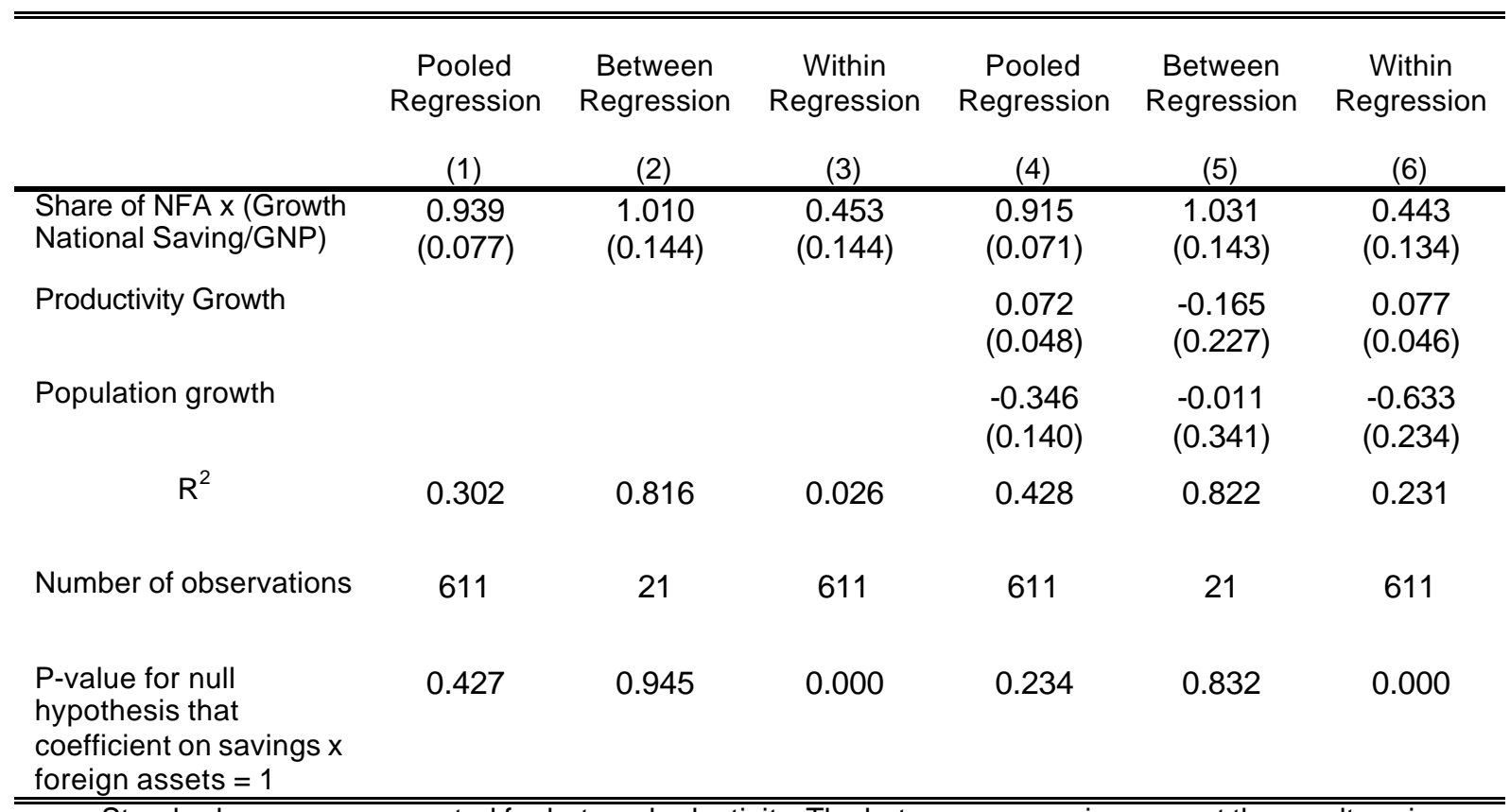

Standard errors are corrected for heteroskedasticity. The between regressions report the results using twenty-one country-averages of all variables, and including a constant. The within regressions report results using country fixed effects. Columns (4) and (6) also include year effects. Constants, country effects, and year effects are not reported. 


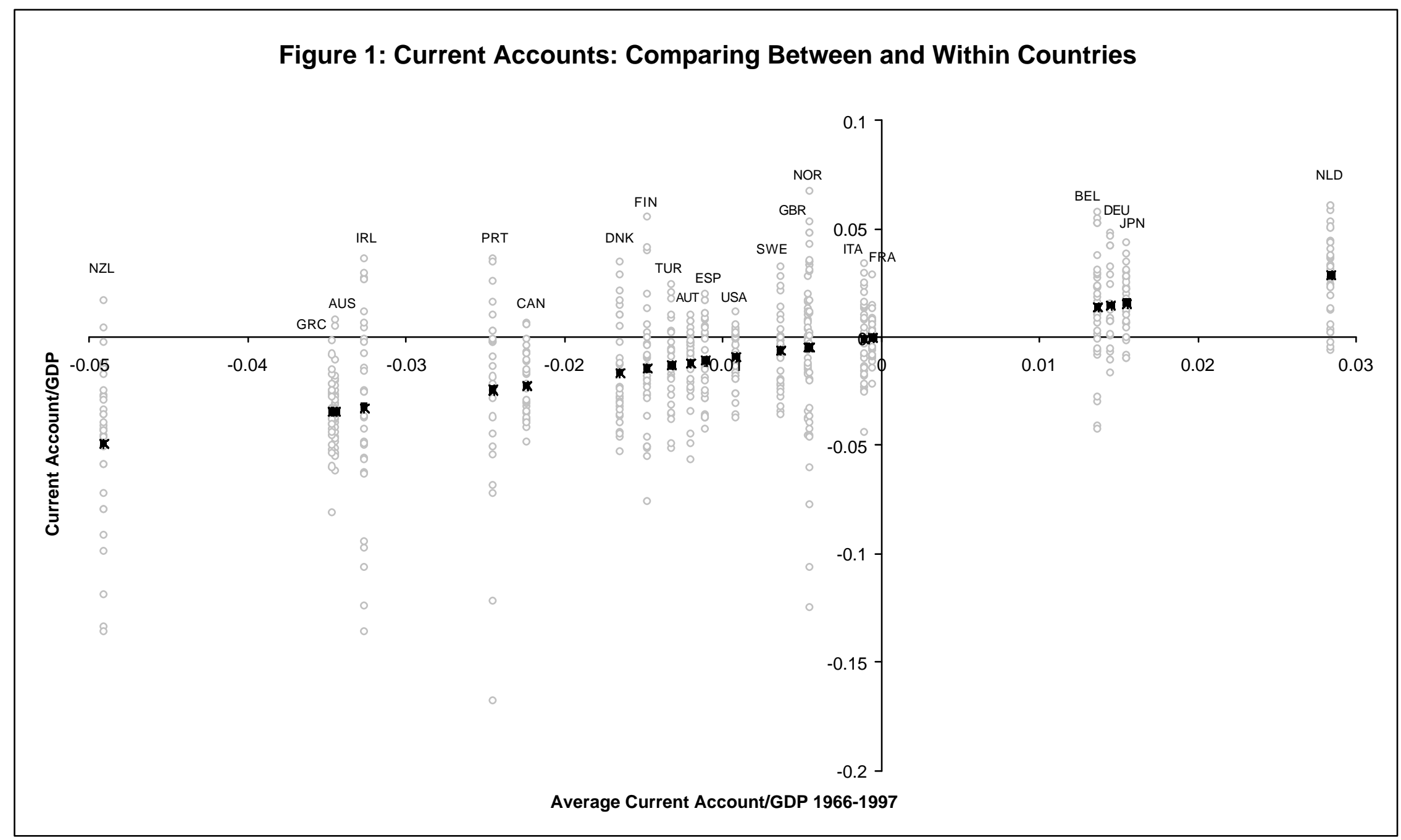

Notes: Unfilled circles are Current Account/GDP for each year. Solid squares represent country-average Current Account/GDP over the period 1966-1997 (connecting the squares hence produces a 45-degree line). The Xaxis shows the dispersion in Current Account/GDP between countries. The Y-axis indicates the time-series variation in Current Account/GDP within countries. 


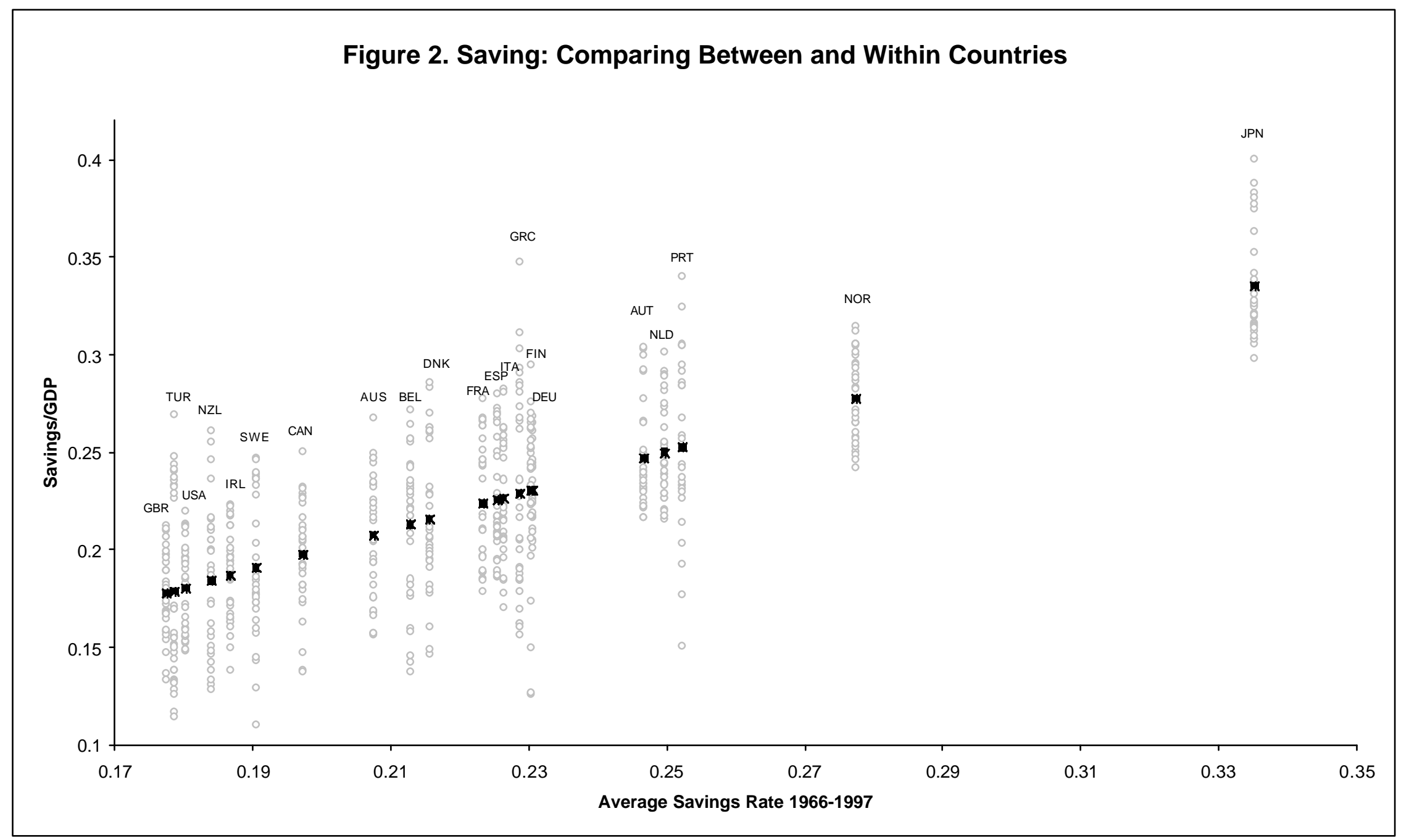

Notes: Unfilled circles are savings rates for each year. Solid squares represent country-average savings rates over the period 1966-1997 (connecting the squares hence produces a 45-degree line). The Xaxis shows the dispersion in savings rates between countries. The Y-axis indicates the time-series variation in savings rates within countries. 
Figure 3: Choosing the country portfolio to maximize return

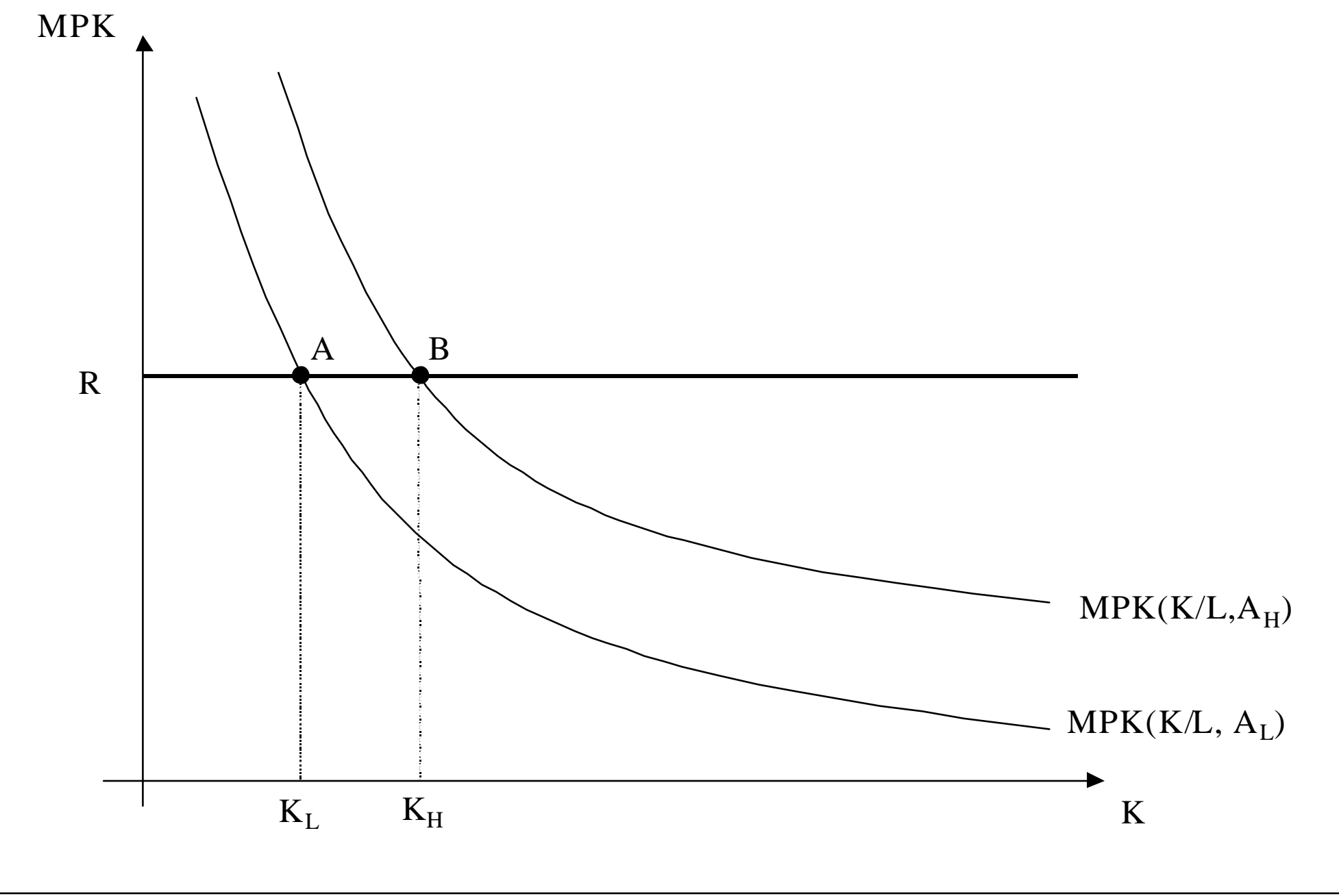




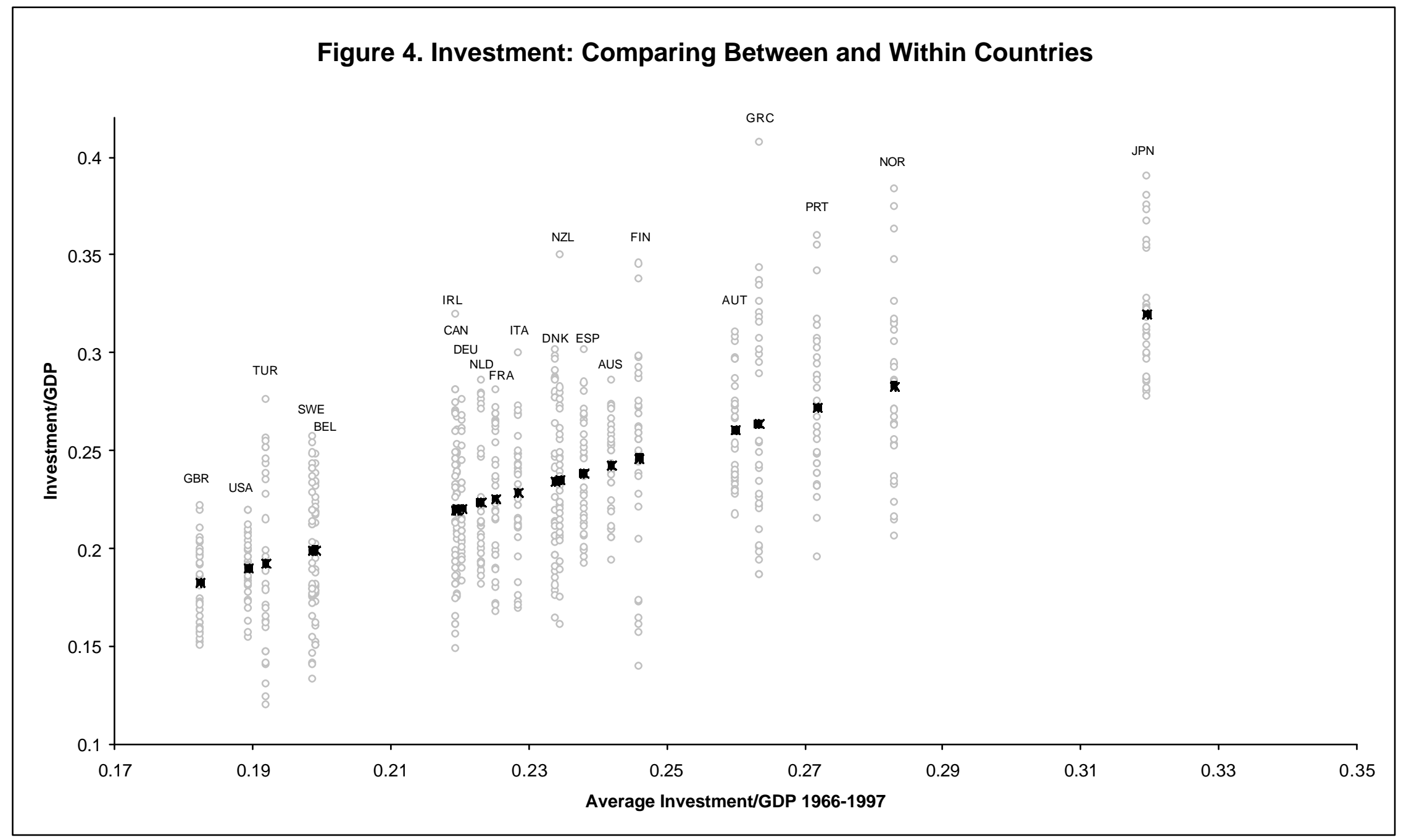

Notes: Unfilled circles are investment rates for each year. Solid squares represent country-average investment rates over the period 1966-1997 (connecting the squares hence produces a 45-degree line). The $\mathrm{X}$-axis shows the dispersion in investment rates between countries. The $\mathrm{Y}$-axis indicates the time-series variation in investment rates within countries. 
Figure 5: Savings and the Current Account
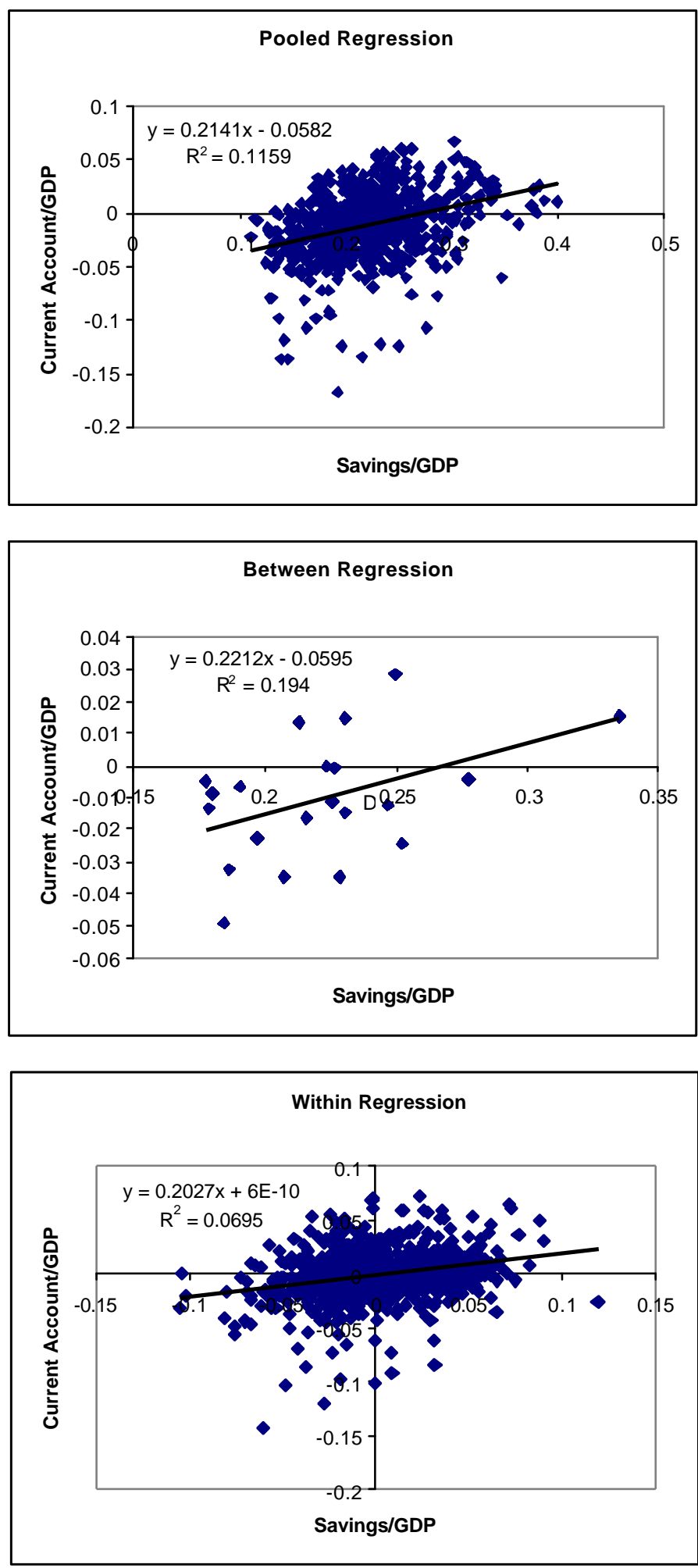


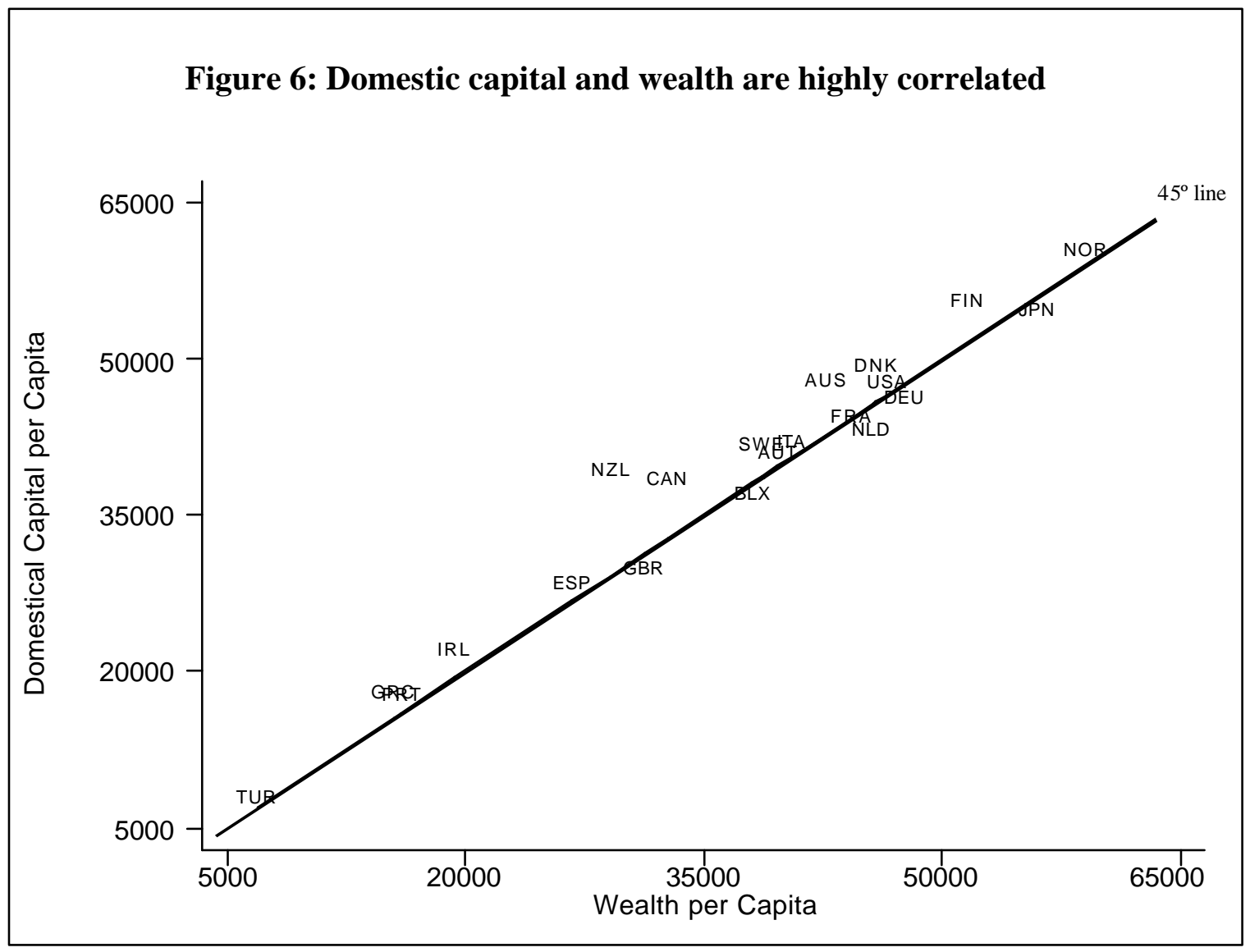


Figure 7: Investment and the Current Account
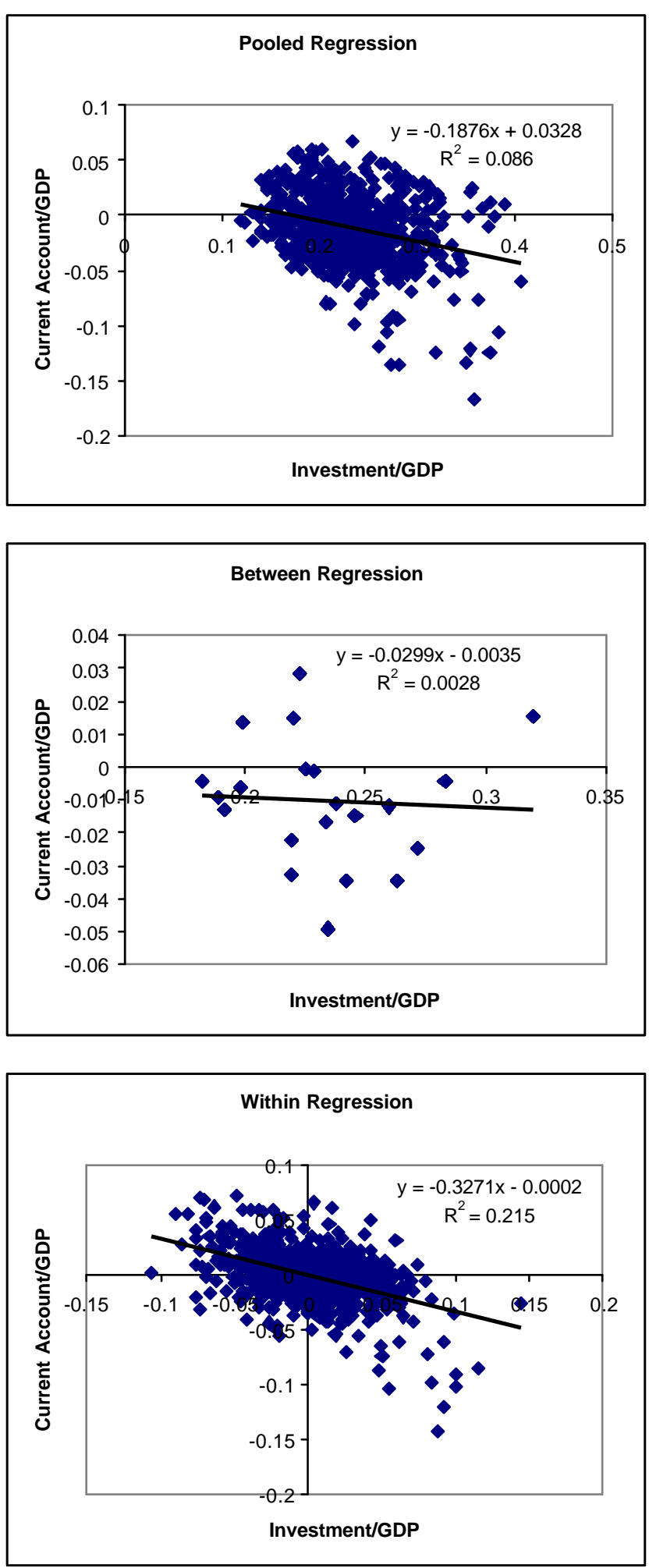


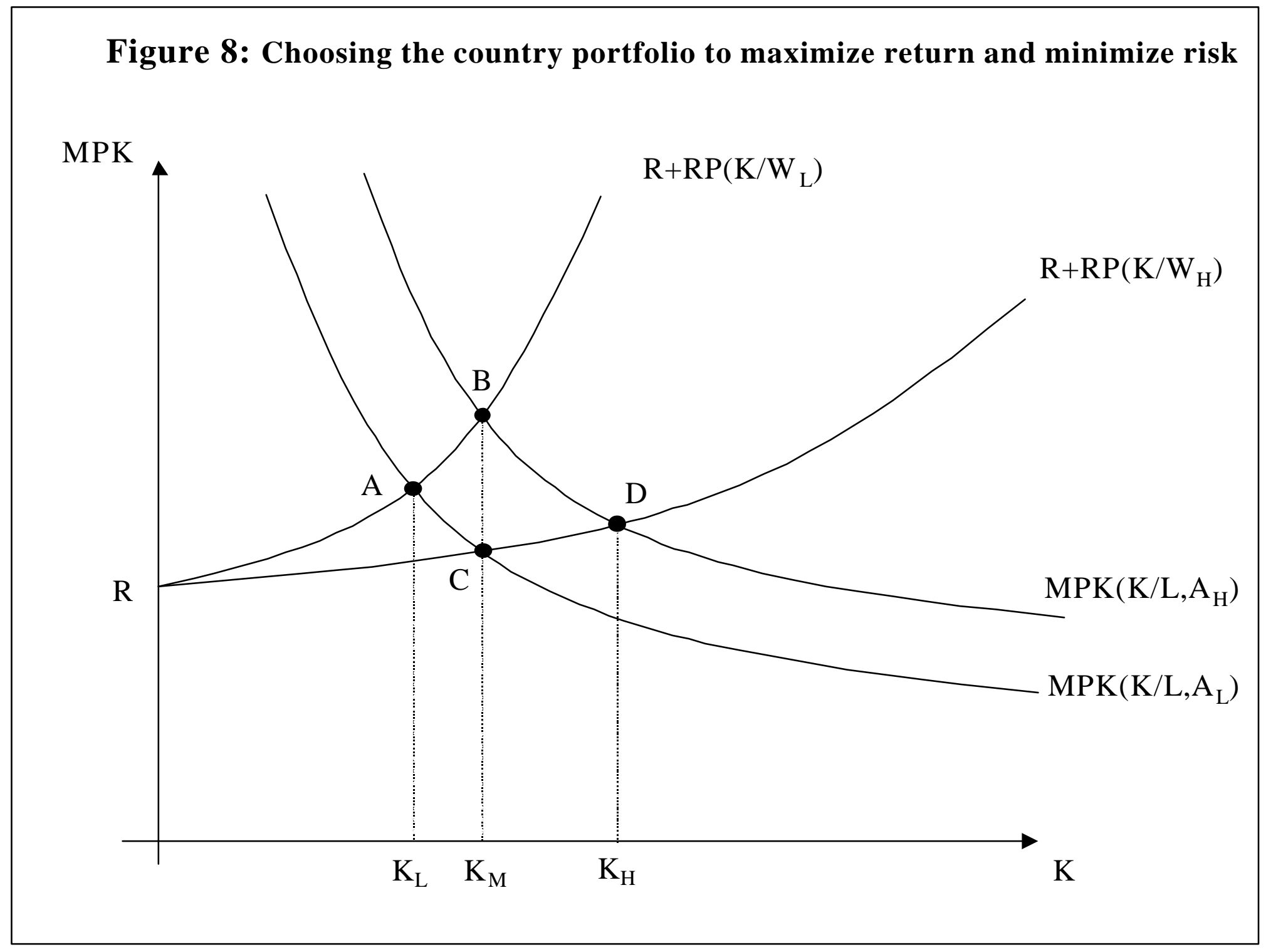




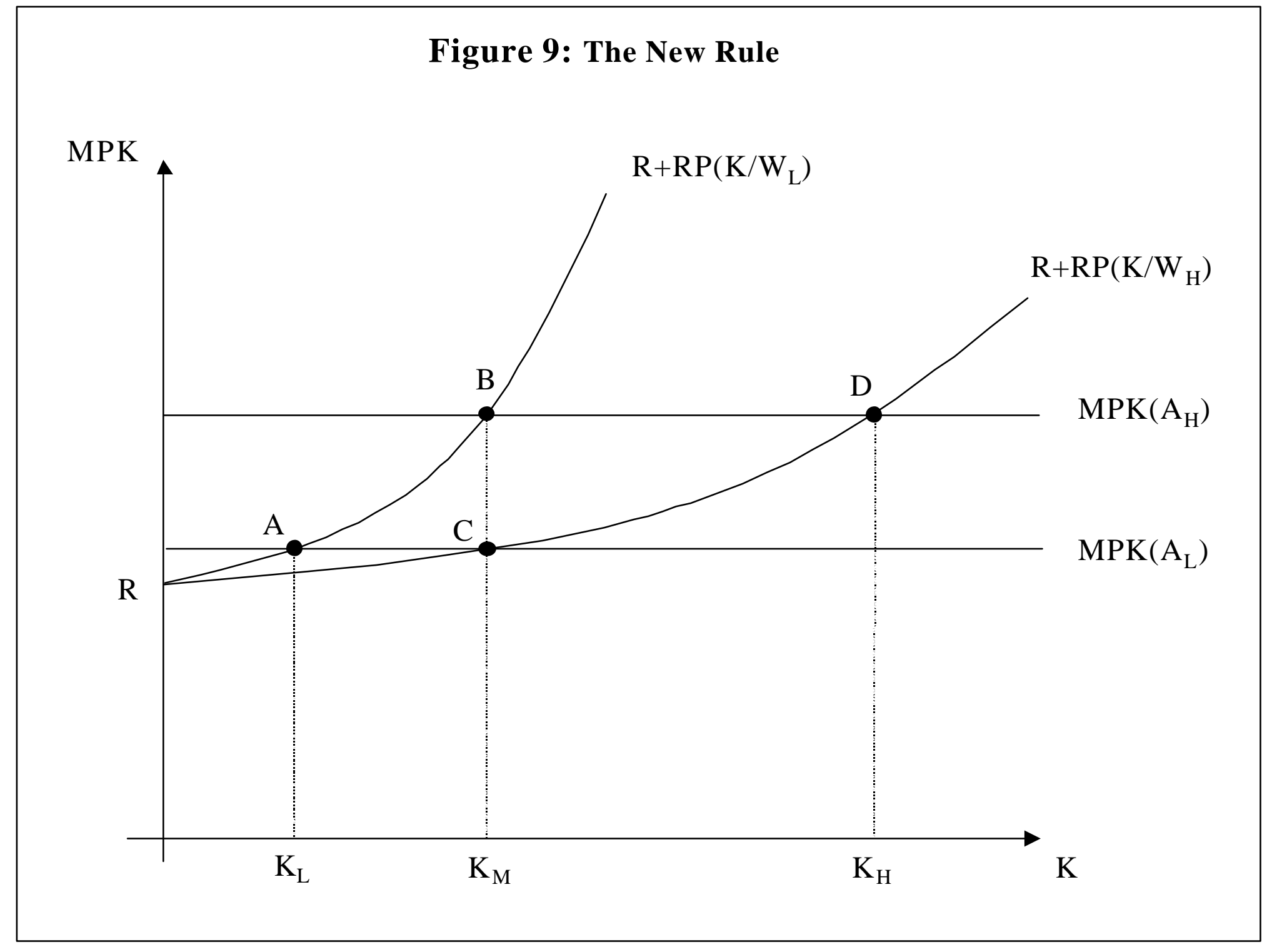




\section{Figure 10: The New Rule and the Current Account}
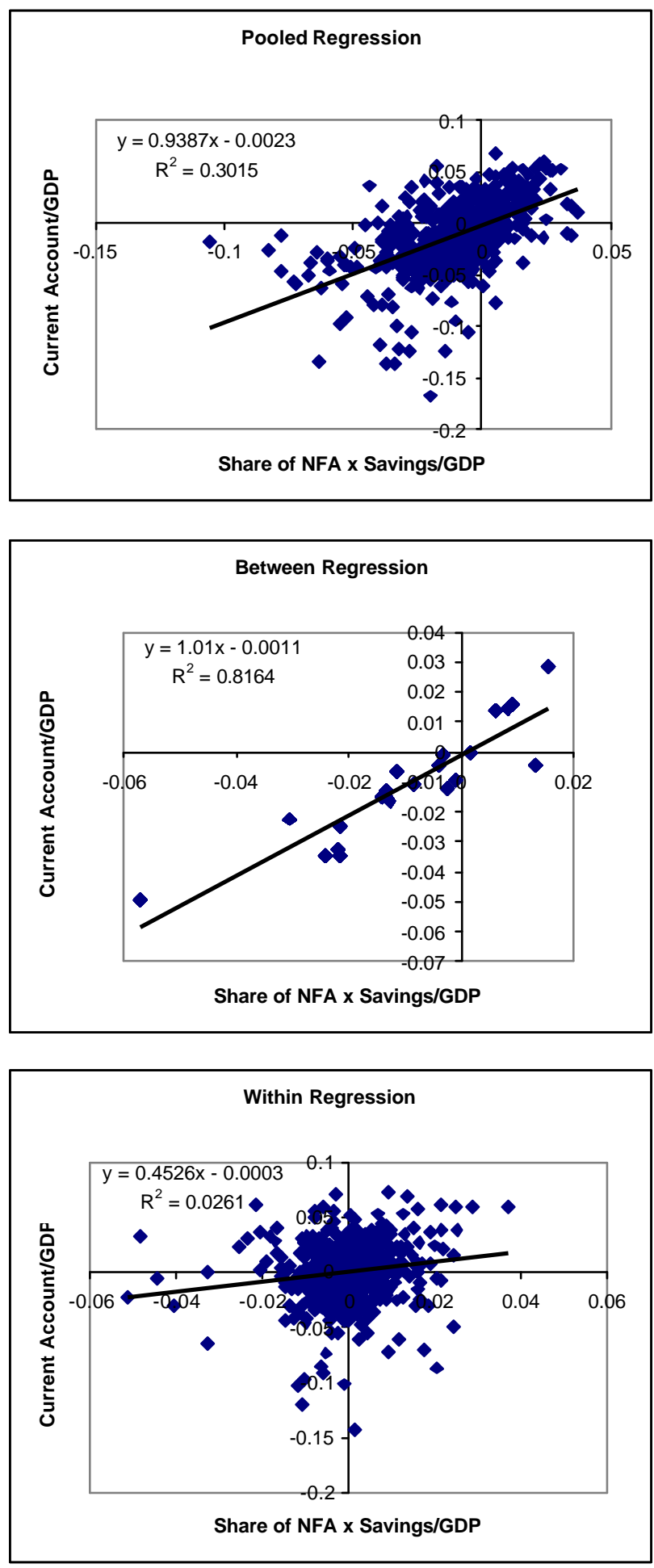


\section{Figure 11: Investment and the Current Account in the Long Run}

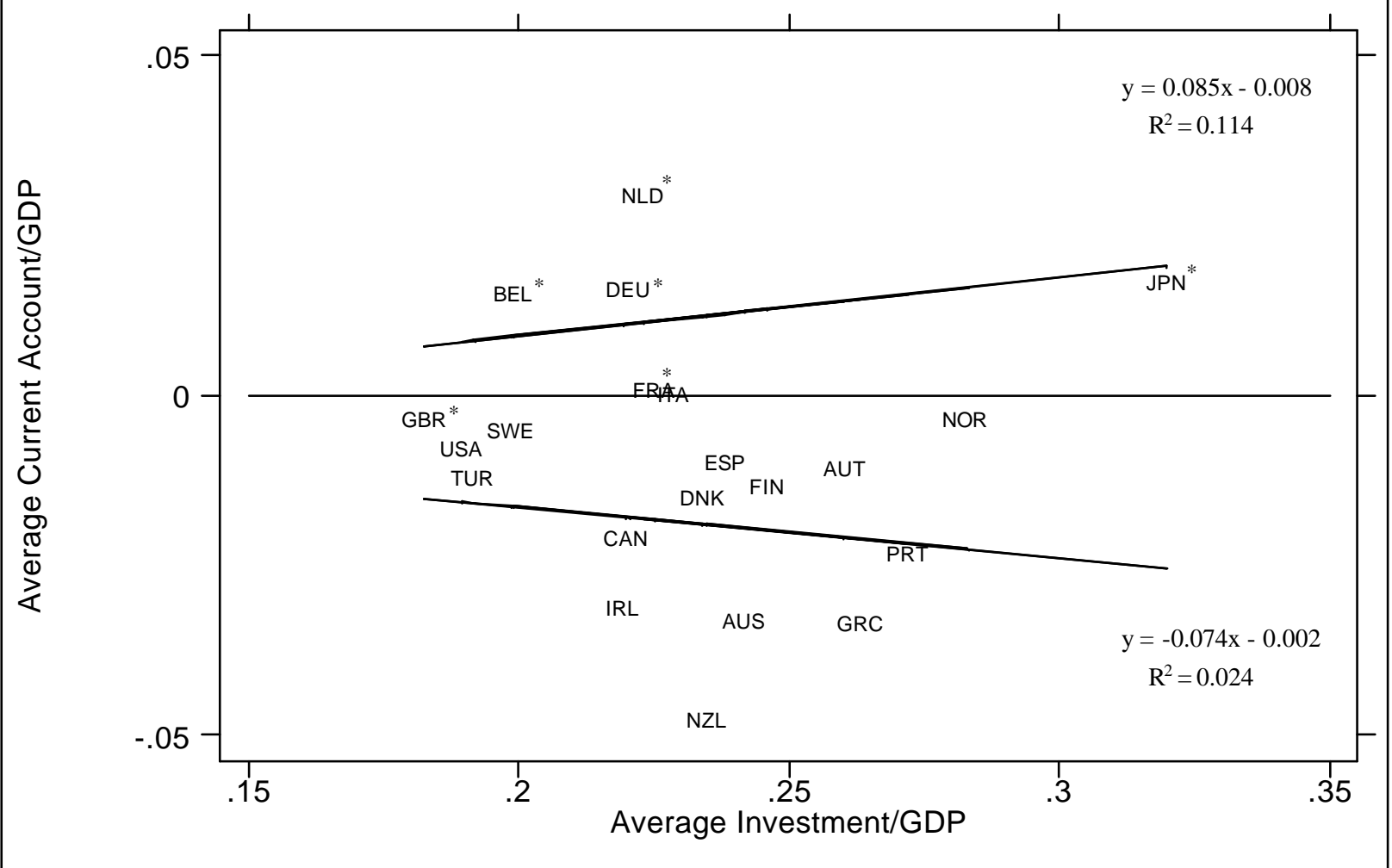

Note: Stars are used to denote countries with positive average net foreign assets, namely Belgium, France, Germany, Netherlands, United Kingdom, and Japan 


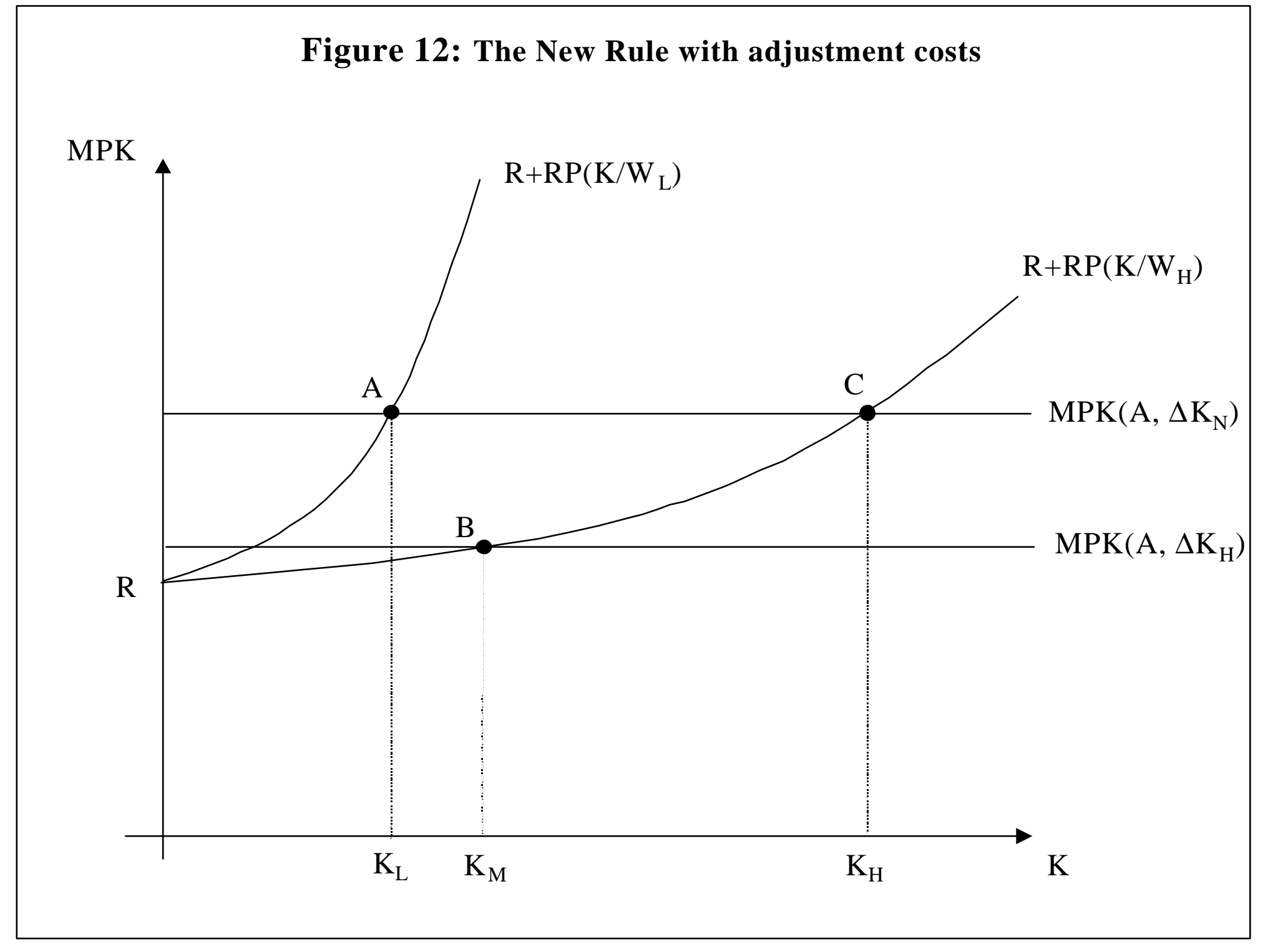

40 


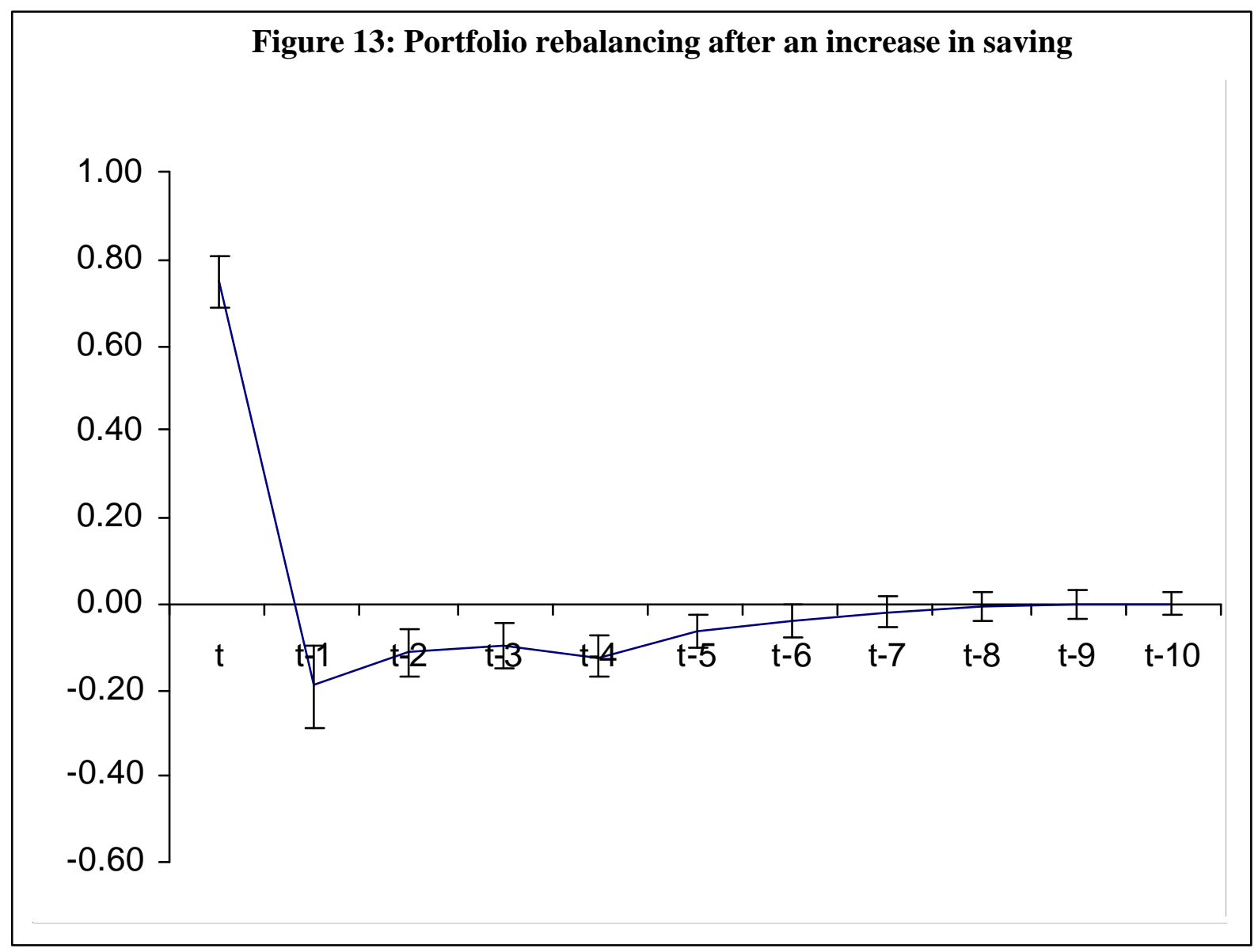

Note: This figure reports the impulse response of the portfolio rebalancing component of the current account to a one-year unit increase in saving. The vertical bars denote one-standard deviation intervals of confidence. 